\title{
Microplastic pollution from sea salt: its effect on public health and prevention alternatives - a review
}

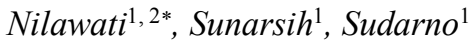 \\ ${ }^{1}$ Master Program of Environmental Sciences, School of Postgraduate, Diponegoro University, \\ Semarang - Indonesia \\ ${ }^{2}$ Center for Industrial Pollution Prevention Technology, Industrial Research and Development \\ Agency, Ministry of Industry, Semarang - Indonesia
}

\begin{abstract}
Salt is a commodity that is needed by everyone. There is a problem because many salts are contaminated with microplastics (MPs). Indonesia to meet the needs of industry with first-class quality salt must be imported. This paper is a review of microplastics from several salt importing countries to Indonesia and also to describe the effect of microplastics for the health public and prevention alternatives. This review used secondary data from total and types (MPs) contamination, amount of salt imports. The results show that almost all salt exports to Indonesia are contaminated by microplastic. Types of microplastic contaminated in Indonesia's sea salt production were tainted with MPs of PE, PP, and PET types. Contamination microplastic from imported salt is PE, PP, PET, Acrylic, nylon, PVC, PS. The number of polluted MPs is the lowest was 09 particles, the higher was $120-718$ particles $/ \mathrm{kg}$ salt. The effect of microplastic on health in the form of cancer, brain function, genetic changes, bronchitis, liver dysfunction, eye irritation. Alternative prevention by recycling plastic waste, changing public behavior in the use of plastics and filtration technology.
\end{abstract}

Keyword. Microplastic pollution, sea salt, effect, alternatives prevention

\section{Introduction}

Plastics are synthetic polymers that are easily shaped (flexible) in nature and can be altered in various forms. Plastics consist of a long chain of polymers composed of carbon, oxygen, hydrogen, silicon, and chloride and obtained from natural gas, oil, and coal [1]. Plasticbased polymer formation through the process of polymerization of the monomer from gas, coal, or petroleum with additives used to produce flexible plastic properties, lightweight and durable $[2,3]$. The basic ingredient of polymer makes plastic waste very difficult to degraded. Plastic waste derived from household and industrial activities there are discarded

\footnotetext{
*Corresponding author: nilawatiqw@gmail.com
} 
on the ground and some are thrown into the river that eventually reaches the waters so polluting the seawater environment.

Plastic waste in the seawater degraded is not the end of the problem of plastic waste pollution caused but the degradation of microplastic and the release of chemical compounds as a result of the degradation process has a harmful potential for the environment [4]. Plastic waste pervasive and increases in groundwater and the environment globally. Most of the plastics in the environment cannot be degraded and remain as waste for a long time [5]. The amount of plastics waste, based on the Ministry of Environment and Forestry 80\% of the garbage thrown into the sea comes from the mainland and $90 \%$ is plastic waste. Plastic waste in Indonesia's oceans is estimated at 187.2 million tons per year [6] Indonesia is currently the second largest country in the world to throw plastic waste into the ocean [6]. In the research concluded that as many as 4.8-12.7 million tons were identified in the oceans. Plastic waste is degraded into microplastic for a long period [7].

Microplastic is one part of the marine debris which potentially threatens more serious than large plastic materials. The small microplastic size allows it to be swallowed by aquatic biota organisms [8]. The lower limit of particle size included in the Microplastic group is not yet defined definitively but most studies take the lower limit of the microplastic size by at least $300 \mu \mathrm{m}$ [9]. Microplastics can be classified into 2 basic groups namely primary and secondary microplastics. The primary microplastic is an industry-made particle used as an additive in commercial formulations. The product combines this type of material including grains in cosmetics, polyethylene particles fragmented in toothpaste, and micro-additives existing synthetic in paints and powder coatings. While the secondary microplastic is a fraction, part, or a fragmentation result of a larger plastic [10]. A secondary microplastic is depicted in chunks of plastic waste derived from discarded plastics [11].

Many research results were done by previous researchers about microplastic contamination originating from the sea, whether it's polluting marine biotic like fish, shrimp, shellfish, squid, crabs, algae, and other animals that live in the sea, and pollute the abiotic product is sea salt. Salt is a commodity that is needed by humans. This salt no one can substitute it. Other than sugar, there is artificial market sugar, such as sugar used for diabetics there is a replacement, but the salt is not so. Sea salt is used for the needs of both the food and non-food industry. The highest use of salt by the pharmaceutical industry. What happens if this salt is contaminated with microplastic.

There is some research on the contamination of microplastics in salts such as [12], salt that originated in the sea, the lake, the well has been contaminated by microplastic. But salt lakes and wells are less contaminated. Total microplastic 4137.3 particles $/ \mathrm{m}^{3}$ in the Yangtze estuary. The average amount of microplastic reaches $5,595 \mathrm{particles} / \mathrm{m}^{3}$ on top of the Hong Kong Coast. The High microplastic content (up to 8714 particles $/ \mathrm{kg}$ ) is also found in the coastal sediment of Hainan island in China. These results show that microplastics are widespread in coastal and sea-estuary environments [13]. Plastic contamination includes FP (Fine Plastic particle size micrometers), MPs (Microplastics size millimeters), and NP (Nano Plastics nanometer size). FP is a powerful adsorbent for toxic hydrophobic pollutants and can affect its toxication in the environment. NP 50 NM showed significant toxicity and physical damage to D. Magna. During the incubation 14 days, the presence of NP significantly increases the bioaccumulation of residues derived from phenanthrene in the body of the Daphnid and inhibits the dissipation and transformation of phenanthrene in the medium, while the 10-mm MP does not exhibit significant effects on bioaccumulation, dissipation, and the transformation of Phenanthrene. There are MPs as much as $100 \mathrm{~g} / \mathrm{L}$ in sediment [14].

The MPs are contaminated, from 128 brands, from 38 countries. Covers more than five continents. 90 percents of commercial salts samples were analyzed containing MPs, with 
concentrations reaching 19800-36135 particles/kg Also, MPs could ignite other contaminants and transfer them from the environment to biotic and abiotic life. Plastic contamination in food including salt in the long term is proven to cause adverse effects in human food safety and health and industry raw materials especially the salt industry.

During this time the national salt needs are met from domestic production and the drawback of imports. Domestic salt production is met by PT.Garam and the people's salts. The salt of popular people from Central Java is generally class II and III, but from PT.Garam with quality I. The quality of the salt is generally the level of $\mathrm{NaCl}$ is still below 94 percent. The quality of salt to date still refers to SNI 3556:2016. But in SNI there is no parameter microplastic. Data on salt imports over the last 3 years in 2017-2019 comes from Australia, China, Germany, New Zealand, India, Singapore, Denmark [15]. Salt from the above countries still contains microplastic [14].

The purpose of writing this manuscript to know the pollution of microplastic in sea salt imported Indonesia from several countries to meet the needs of the industry as well as the influence of microplastic to health and also provide alternative prevention measures microplastic pollutants.

\section{Method}

This paper is a review so the data used is secondary data and material from the Science Direct journals, ELSEVIER from 2015-2020, with Microplastics (MPs), Sea Salt, toxicity MPs. Then collected the data of the secondary includes the data of salt needs and production, data import, microplastic data from countries in the world especially the importing country of salt to Indonesia. Data on salt imports in 2017-2019 [15]. The Data of microplastic contamination from various countries [14].

\section{Result and Discussion}

\subsection{Production and Import Salt in Indonesia}

Salt in Indonesia is much absorbed by the industry with the quality of salt K1 or about 30 percent of the entire salt. While the quality salt of $\mathrm{K} 2$ and $\mathrm{K} 3$ is used for the salt industry household consumption. Nevertheless, household salt does not absorb as much as other industries such as the pharmaceutical industry. Of the 3 million tons, the possible absorption is only 600,000 tons.

The needs of salt in Indonesia are fulfilled by domestic production and import. From the Data collection shows the import data of salt and domestic salt production, as presented in table 1 [15]. For the contamination of microplastics in salt as it is written Peixoto, D, et al., 2019 , can be seen table 2 where imports of salt from some countries are seen almost all the domestic importer contains microplastic with varied types including salt from domestic production (Indonesia) also contaminated microplastic. 
Table 1. Data Import Salt (x1000 kg) in Indonesia $[14,15]$

\begin{tabular}{ccccccc}
\hline No & Country Origin & 2017 & 2018 & 2019 & MPs \\
\hline 1 & Australia & $2.296 .681,3$ & 2.603 .186 & $1.869 .684,2$ & $0-9$ \\
& & & & $0-9$ \\
& & & & 80 \\
2 & India & $251.590,1$ & $227.925,6$ & $719.550,4$ & $56-103$ \\
3 & Tiongkok & 219,2 & 899,7 & 568 & $500-681$ \\
& & & & & $120-718$ \\
4 & New Zealand & $2.699,5$ & $3.806,8$ & $4.052,4$ & $43-364$ \\
5 & Singapura & 121,5 & 239,0 & 229,3 & 28 \\
6 & German & 300,1 & 236,0 & 243,0 & $0-1$ \\
7 & Denmark & 486,8 & 816,7 & 496,2 & $7-204$ \\
8 & Others & 704,7 & $1.967,96$ & 573,8 & $0-1300$ \\
& Amount & $2.552 .823,2$ & $2.839 .077,4$ & $2.595 .397,3$ & \\
\hline
\end{tabular}

For domestic production during the years $2017,2018,2019$ respectively 1.1 million; 2.7 million; 2,300,000 Ton.

Table 2: Microplastics Contaminant in Sea Salt and Types of MPs [14]

\begin{tabular}{|c|c|c|c|c|}
\hline No & Origin & $\begin{array}{c}\text { MPs } \\
\text { (particles } \\
/ \mathrm{kg} \text { ) }\end{array}$ & Size $(\mu \mathrm{m})$ & Type of MPs \\
\hline 1 & Australia (Indic Ocean) & $0-9$ & $160-980$ & PE, PET \\
\hline 2 & Australia (Pacific Ocean) & $0-9$ & $160-980$ & PE, PET \\
\hline 3 & Australia (Pacific Ocean) & 80 & $100-3000$ & $\begin{array}{l}\text { Acrylic, Nylon, PE, PET, PP, } \\
\text { PS }\end{array}$ \\
\hline 4 & India (Indic Ocean) & $56-103$ & $500-2000$ & PA, PE, PET, PS \\
\hline 5 & China (Pacific Ocean) & $500-681$ & $<100,>1000$ & $\begin{array}{l}\text { CP, CI, PAN, PB, PE, PES, } \\
\text { PET, PP, POM, PMA }\end{array}$ \\
\hline 6 & China (Pacific Ocean) & $120-718$ & $100-4000$ & $\begin{array}{l}\text { Acrylic, Nylon, PE, PET, PP, } \\
\text { PVC, PW }\end{array}$ \\
\hline 7 & China (Continental) & $43-364$ & $<100,>1000$ & $\begin{array}{l}\text { PET, PES, PB, PP, PE-PP, } \\
\text { POM, PAK, CP }\end{array}$ \\
\hline 8 & China (Continental) & 28 & $100-2000$ & PE, PET, PP, PS, Teflon \\
\hline 9 & China (Continental) & $7-204$ & $<100,>1000$ & $\begin{array}{l}\text { PET, PE, PB, PP, PE-PP, } \\
\text { POM, PAN, PVC }\end{array}$ \\
\hline 10 & $\begin{array}{l}\text { China Taipei (Pacific } \\
\text { Ocean) }\end{array}$ & $0-1300$ & $100-5000$ & $\begin{array}{l}\text { Nylon, EVA, PE, PET, PP, } \\
\text { PVC, PW }\end{array}$ \\
\hline 11 & $\begin{array}{l}\text { New Zealand (Pacific } \\
\text { Ocean) }\end{array}$ & $0-1$ & $160-980$ & $\mathrm{PE}$ \\
\hline 12 & German (Continental) & 2 & 100 & PET \\
\hline 13 & Indonesia & 100 & $100-2000$ & PE, PP, PET \\
\hline
\end{tabular}

Almost all imported salts are contaminated by microplastics, for the Australian state there is no pollution. The occurrence of microplastic contamination in salt plantations is caused by seawater contamination. Almost all seas in the world are contaminated with microplastics [10]. It is also said that the microplastic Composition floating on the ocean categories of microplastics were polyethylene (PE), polypropylene (PP), polystyrene (PS), and polyethylene terephthalate (PET), which accounted for $51 \%, 29 \%, 16 \%$, and $3 \%$. The microplastic-contaminated sea at black sea watrs, central western mediterranean sea, northeast pasific, seto island, east asian sea, southeast korea, sourthern california, northeast atlantic, artic polar waters, east china sea, bohai sea china and sawu sea [10]. 


\subsection{Effect of Contamination microplastics in Public Health}

Microplastic can cause adverse effects for marine organisms because it absorbs persistent organic pollutants (POP) over a long period [17]. Fine Plastics particles (FPs) contamination including Microplastics (MPs) and Nano plastics (NPs). FPs are strong pollutants hydrophobic toxic and also toxicity in environmental [13].

The reports that plastics provide an effect on environmental habitats because plastic properties in addition to containing contaminants also can absorb contaminants from the environment, remove and distribute contaminants into the environment [14].

Research [10] microplastics affect the growth of microalgae, after 96 hours of microplastic exposure, the microalgae growth was blocked up to 39.7 percent. Microalgae are one of the very high types of seafood. Microalgae components can be transformed into industrial raw materials in the form of biodiesel, ethanol, and pharmaceutical chemistry [18].

Table 3. Types of Plastics [20]

\begin{tabular}{|c|c|c|c|c|}
\hline $\begin{array}{l}\text { Types of } \\
\text { plastics }\end{array}$ & $\begin{array}{l}\text { Density } \\
\left(\mathrm{g} / \mathrm{cm}^{3}\right)\end{array}$ & Source & Effect on health & $\begin{array}{l}\text { Specific } \\
\text { Gravity } \\
{[19]}\end{array}$ \\
\hline $\begin{array}{l}\text { Polystyrene } \\
\text { (PES) }\end{array}$ & $1.04-1.08$ & $\begin{array}{l}\text { Plates, cutting tools, } \\
\text { optical diskette, toys }\end{array}$ & $\begin{array}{l}\text { Eye and respiratory } \\
\text { irritation, } \\
\text { carcinogenic in } \\
\text { humans }\end{array}$ & 1,4 \\
\hline $\begin{array}{l}\text { Expanded } \\
\text { Polystyrene } \\
\text { (PES) }\end{array}$ & $0,01-0,04$ & $\begin{array}{l}\text { Foam plates, plates, } \\
\text { trays, clamshell } \\
\text { containers }\end{array}$ & $\begin{array}{l}\text { Eye and respiratory } \\
\text { irritation, } \\
\text { carcinogenic in } \\
\text { humans }\end{array}$ & 1,4 \\
\hline $\begin{array}{l}\text { Low-Density } \\
\text { Polyethylene } \\
\text { (LDPE) }\end{array}$ & $0,94-0,98$ & $\begin{array}{l}\text { Lid containers, } \\
\text { wrapping containers, } \\
\text { blackmail bottles, } \\
\text { tubes, diapers, bullet } \\
\text { rifles }\end{array}$ & $\begin{array}{l}\text { Removing } \\
\text { estrogenic chemicals } \\
\text { that cause changes } \\
\text { in human cell } \\
\text { structures }\end{array}$ & $0,917-0,93$ \\
\hline $\begin{array}{l}\text { High-Density } \\
\text { Polyethylene } \\
\text { (HDPE) }\end{array}$ & $0,94-0,98$ & $\begin{array}{l}\text { Detergent and } \\
\text { household cleaning } \\
\text { bottles, milk teapots, } \\
\text { grocery bags, } \\
\text { recycling bins, } \\
\text { playground } \\
\text { equipment }\end{array}$ & $\begin{array}{l}\text { Removing } \\
\text { estrogenic chemicals } \\
\text { that cause changes } \\
\text { in human cell } \\
\text { structures }\end{array}$ & 0,93-097 \\
\hline $\begin{array}{l}\text { Polyamide } \\
\text { (PA) }\end{array}$ & $\begin{array}{l}1.13-1.16 \\
1.13-1.16\end{array}$ & $\begin{array}{l}\text { Fur toothbrush, } \\
\text { fishnet, and rope }\end{array}$ & $\begin{array}{l}\text { Removing } \\
\text { estrogenic chemicals } \\
\text { that cause changes } \\
\text { in human cell } \\
\text { structures }\end{array}$ & \\
\hline
\end{tabular}


Table 4. (Continue)

\begin{tabular}{|c|c|c|c|c|}
\hline $\begin{array}{l}\text { Types of } \\
\text { plastics }\end{array}$ & $\begin{array}{l}\text { Density } \\
\left(\mathrm{g} / \mathrm{cm}^{3}\right)\end{array}$ & Source & Effect on health & $\begin{array}{l}\text { Specific } \\
\text { Gravity } \\
{[19]}\end{array}$ \\
\hline $\begin{array}{l}\text { Polypropylene } \\
\text { (PP) }\end{array}$ & $0,85-0,92$ & $\begin{array}{l}\text { Auto parts, food } \\
\text { containers, tableware, } \\
\text { bottle caps }\end{array}$ & $\begin{array}{l}\text { Cause damage to liver } \\
\text { function, changes in } \\
\text { insulin resistance and } \\
\text { brain function }\end{array}$ & $090-0,92$ \\
\hline $\begin{array}{l}\text { Acrylonitrile } \\
\text { Butadiene } \\
\text { styrene }\end{array}$ & $1.04-1.06$ & $\begin{array}{l}\text { Electronic equipment } \\
\text { casing, pipe }\end{array}$ & $\begin{array}{l}\text { Removing } \\
\text { estrogenic chemicals } \\
\text { that cause changes } \\
\text { in human cell } \\
\text { function }\end{array}$ & \\
\hline $\begin{array}{l}\text { Cellulose } \\
\text { Acetate (CA) }\end{array}$ & 1.30 & Cigarette filter & & \\
\hline $\begin{array}{l}\text { Polycarbonate } \\
\text { (PC) }\end{array}$ & $1.20-1.22$ & Disk optic & $\begin{array}{l}\text { Cause cancer } \\
\text { Bisphenol will } \\
\text { release from } \\
\text { polycarbonate and } \\
\text { cause damage to } \\
\text { liver function, } \\
\text { changes in insulin } \\
\text { resistance and brain } \\
\text { function }\end{array}$ & 1,05 \\
\hline $\begin{array}{l}\text { Polymethyl } \\
\text { methacrylate } \\
\text { (PMMA) }\end{array}$ & $1.20-1.22$ & $\begin{array}{l}\text { Optical lenses, paints, } \\
\text { anti-shattered } \\
\text { windows }\end{array}$ & & \\
\hline $\begin{array}{l}\text { Polyvinyl } \\
\text { Chloride (PVC) }\end{array}$ & $1.38-1.41$ & $\begin{array}{l}\text { Textiles, soft drinks, } \\
\text { and bottled water }\end{array}$ & $\begin{array}{l}\text { Cancer, genetic } \\
\text { changes, bronchitis } \\
\text { chronic, skin } \\
\text { diseases, liver } \\
\text { dysfunction }\end{array}$ & $1,16-1,30$ \\
\hline $\begin{array}{l}\text { Polyethyle } \\
\text { ne } \\
\text { terephthala } \\
\text { te (PET) }\end{array}$ & $2.10-2.30$ & $\begin{array}{l}\text { Textiles, soft drinks, } \\
\text { and water bottles }\end{array}$ & $\begin{array}{l}\text { Eye and respiratory } \\
\text { irritation, } \\
\text { carcinogenic in } \\
\text { humans }\end{array}$ & 1,37 \\
\hline
\end{tabular}

\subsection{Microplastic Bioaccuumulation}

In marine environments, microplastics are of various sizes, forms, and chemical compositions. MPs are found at sea level, deposits, water columns, and in wildlife. The most common type of plastic polymer in the sea is polyethylene and polypropylene [20]. 
According to [21] that salt from the sea contains microplastic Due to anthropogenic activity, found 25 samples in South India using the method of FTIR analyzed 60 percent of the pollutants Are MPs. The type IS PP, PE, nylon, and cellulose.

Plastic waste is very potential to pollute the environment because plastic has a difficult nature degraded so that if done a stock fill it will give many problems [22].

When Microplastic is in water it will float depending on the density of Polymer. A floating microplastic capability determines the microplastic position in the water and its interactions with biota [23]. More Polymers Solid from seawater such as PVC will settle while the density of the Redah such as PE and PP will float. As long as it is in the water of plastic particles subjected to biofouling, colonization of organisms to sink. Microplastics can also be degraded, fragmented, and remove the adhesive material so that the particles will change density and distributed between the surface and the base of the water. Type of plastic based on origin and density of polymer or heavy type.

\subsection{Alternative Microplastic Contamination prevention efforts}

\subsubsection{Changing people's behaviors in plastic wear}

Plastics and human life cannot be separated from the plastic. Urban communities prefer a practical life pattern by using plastic for packaging. But this life pattern is unfortunate because it is not followed by plastic waste management. According to Indonesian law number 28 the year 2008 about waste management which was originally considered to be a policy reference that accelerates the effectiveness of handling waste management nationally and at the regional level [24]. People should reduce the use of waste, getting used to going shopping by carrying their bags. Food vendors should not provide a straw because the amount of straw produced is high enough for each type of beverage that needs to be 1 straw, which is used 1-time use. Counseling is provided with the method of counseling and evaluation with the post-evaluation Questionnaire [25].

\subsubsection{Recycle plastic waste}

Data on Sustainable Waste Indonesia, less than $10 \%$ recycled plastic waste, and over $50 \%$ remained in landfills. The United States used a plastic average of 38 million kilograms per day and succeeded in plastic waste management until the 'mismanaged plastic waste' number does not exist. Unlike China and Indonesia, although the use of plastics in China 32 million kilograms per day, but plastic waste that cannot be managed until 24 million kg per day. So Indonesia, the use of 11 million kilograms per day, but the unmanaged garbage is good to reach 9 million kilograms per day. Managing the garbage that is already there, there needs to be a circular economy. The circular economy makes the cycle between production, consumption, and recycling to no waste. With a circular economy, it will reduce the extraction of natural resources, add jobs, increase direct and indirect economies, reduce waste to landfill and improve environmental quality.

The creative activity of plastic waste can also be one of the Community empowerment movement and expand the job field and open the possibility of improving the welfare of the community. Garbage sorting into 3 groups, namely organic waste, inorganic and plastic waste. Organic waste is processed independently in each house into compost, some plastic waste is used into handicrafts, and another inorganic waste is channeled to the presses to be processed again. The success of this simple system is continuously located in the solidarity, intent, and motivation of the waste management team and the cooperation of all elements of society. Without good cooperation and reception, this system certainly cannot walk. This 
concept is carried out with 4 principles, namely self-administering society; productive that produces something up to value; Comprehensive, the whole garbage can be controlled and environmentally friendly namely manage the garbage so it does not pollute the environment [26].

\subsubsection{Technology Filtration}

This filtration technology can be used when seawater enters the salt Pond plantation by using a filer smaller than $5 \mu \mathrm{m}$ so that microplastic particles cannot pass into the salt fields. The other revew gave result that bioreactor membrane technology can elimitted MPs up to 99 percent and the empirical infuence factors are pore size, shape thickness membrane, surface properties the shape of the MPs particles affects their removal efficiency and can determine the interaction between other contaminants or microorganisms. The shape is categorized as fiber, granular, fragment, film, and foam [27].

\section{Conclusion}

1. Salt is a commodity that is needed by humans without any substitute.

2. All the waters In the world have been contaminated microplastic

3. Sea salt has been contaminated microplastic from plastic waste degraded into microplastics into the area of salt plantations

4. Almost all imported salts are contaminated with microplastic from foreign sea salts such as China, India, New Zealand, Germany, Denmark, and salt in Indonesia.

5. Type of microplastic that pollutes sea salt is a type of Acrylic, Nylon, PE, PET, PP, PS, for Indonesia, PE, PP and PET

6. The effect of microplastic on health is causing cancer, damage to liver function, changes in insulin resistance, and brain function. Genetic changes, bronchitis chronic, skin diseases, liver dysfunction, eye irritation

7. Alternative prevention by recycling plastic waste, changing the behavior of people in the use of plastics, filtration technology and polluted water source.

\section{Acknowledgment}

The authors express their deepest gratitude to Mrs. Sunarsih and Mr. Sudarno as a lecturer at the Master Program of Environmental Sciences, School of Postgraduate Diponegoro University who has provided support and guidance. We also thank the anonymous reviewers for their valuable comments to improve the manuscript.

\section{References}

[1] S. Chatterjee and S. Sharma, "Microplastics In Our Oceans and Marine Health," F. Actions Sci. Rep., 19, no. 19, pp. 54-61 (2019).

[2] J. Hammer, M. H. S. Kraak, and J. R. Parsons, Plastics in the Marine Environment: The Dark Side of a Modern Gift, 220 (2012).

[3] M. Kosuth, S. A. Mason, and E. V. Wattenberg, "Anthropogenic contamination of tap water, beer, and sea salt," PLoS One, 13, no. 4, pp. 1-18 (2018).

[4] B. Gewert, M. M. Plassmann, and M. Macleod, "Pathways for degradation of plastic polymers floating in the marine environment," Environ. Sci. Process. Impacts, 17, no. 9, pp. 1513-1521(2015). 
[5] R. M. Blair, S. Waldron, V. Phoenix, and C. Gauchotte-Lindsay, "Micro- and Nanoplastic Pollution of Freshwater and Wastewater Treatment Systems," Springer Sci. Rev., 5, no. 1-2, pp. 19-30 (2017).

[6] W. Jambeck, J.R., Geyer, R., P. C., Siegler, T.R., and K. . M., Andrady, A., Law, "Plastic Waste Inputs From Land Into The Ocean," Science (80-. ), 347, no. 6223, pp. 768-771 (2015).

[7] M. Haward, "Plastic pollution of the world's seas and oceans as a contemporary challenge in ocean governance," Nat. Commun., 9, no. 1, pp. 9-11 (2018).

[8] M. S. Mauludy, A. Yunanto, and D. Yona, "Microplastic Abundances in the Sediment of Coastal Beaches in Badung, Bali," J. Perikan. Univ. Gadjah Mada, 21, no. 2, p. 73(2019).

[9] F. R. Storck, T. Karlsruhe, S. A. E. Kools, S. Rinck-Pfeiffer, and GWRC, Science Brief: Microplastics in Fresh Water Resources, (2015).

[10] W. Zhang et al., "Microplastic pollution in the surface waters of the Bohai Sea, China," Environ. Pollut., 231, pp. 541-548, 2017.

[11] S. A. Carr, "Sources and dispersive modes of micro-fibers in the environment,"Integr. Environ. Assess. Manag., 13, no. 3, pp. 466-469 (2017.

[12] D. Yang, H. Shi, L. Li, J. Li, K. Jabeen, and P. Kolandhasamy, "Microplastic Pollution in Table Salts from China," Environ. Sci. Technol., 49, no. 22, pp. 1362213627 (2015).

[13] Y. Ma et al., "Effects of nanoplastics and microplastics on toxicity, bioaccumulation, and environmental fate of phenanthrene in fresh water," Environ. Pollut., 219, pp. 166-173 (2016).

[14] D. Peixoto, C. Pinheiro, J. Amorim, L. Oliva-Teles, L. Guilhermino, and M. N. Vieira, "Microplastic pollution in commercial salt for human consumption: A review," Estuar. Coast. Shelf Sci., 219, pp. 161-168 (2019).

[15] Badan Pusat Statistik, "Impor Garam Menurut Negara Asal Utama." [Online]. Available: https://www.bps.go.id/statictable/2019/02/14/2013/impor-garam-menurutnegara-asal-utama-2010-2019.html.

[16] A. Karami, A. Golieskardi, C. Keong Choo, V. Larat, T. S. Galloway, and B. Salamatinia, "The presence of microplastics in commercial salts from different countries," Sci. Rep.,7, no. March, pp. 1-11 (2017).

[17] S. Khoironi, A., Anggoro, S., "Evaluation of the Interaction Among Microalgae Spirulina sp, Plastics Polyethylene Terephthalate and Polypropylene in Freshwater Environment Adian," J. Ecol. Eng., 20, no. 6, pp. 153-160 (2019).

[18] A. Djunaedi, C. Adi, and A. Santosa, "Kandungan Pigmen Fikobiliprotein dan Biomassa Mikroalga Chlorella vulgaris pada media dengan Salinitas Berbeda," 20, no. November, pp. 112-116 (2017).

[19] A. Lusher, P. Hollman, and J. . J. Mandoza-Hill, Microplastics in fisheries and aquaculture,. 615, no. July. 2017.

[20] M. Smith, D. C. Love, C. M. Rochman, and R. A. Neff, "Microplastics in Seafood and the Implications for Human Health," Curr. Environ. Heal. reports, 5, no. 3, pp. 375386 (2018).

[21] S. Selvam, A. Manisha, S. Venkatramanan, S. Y. Chung, C. R. Paramasivam, and

C. Singaraja, "Microplastic presence in commercial marine sea salts: A baseline study along Tuticorin Coastal salt pan stations, Gulf of Mannar, South India," Mar. Pollut. Bull., 150, p. 110675 (2020).

[22] F. L. Sahwan, D. H. Martono, S. Wahyono, and L. A. Wisoyodharmo, "Sistem Pengelolaan Limbah Plastik di Indonesia," J. Sist. Pengolah. Limbah J. Tek. Ling. P3TL-BPPT, 6, no. 1, pp. 311-318 (2005). 
[23] S. L. Wright, R. C. Thompson, and T. S. Galloway, "The physical impacts of microplastics on marine organisms: a review.," Environ. Pollut., 178, pp. 483-492 (2013).

[24] Undang Undang Republik Indonesia, Undang-Undang Republik Indonesia Nomor 18 Tahun 2008 Tentang Pengelolaan Sampah. 2008.

[25] E. Ilmiawati, Cimi. Reza, Mohamad., Rahmatini., Rustam, "Edukasi Pemakaian Plastik Sebagai Kemasan Makanan Dan Minuman Serta Risikonya Terhadap Kesehatan Pada Komunitas Di Kecamatan Bungus Teluk Kabung, Padang," J. Chem. Inf. Model., 53, no. 9, pp. 1689-1699 (2019).

[26] H. P. Putra and Y. Yuriandala, "Studi Pemanfaatan Sampah Plastik Menjadi Produk dan Jasa Kreatif," J. Sains \&Teknologi Lingkung., 2, no. 1, pp. 21-31, (2010).

[27] T. Poerio, E. Piacentini, and R. Mazzei, "Membrane processes for microplastic removal," Molecules, 24, no. 22 (2019). 